\title{
The Entrepreneurship Factors on Handicapped Business Owner in Malang Indonesia
}

\author{
Uci Yuliati \\ University of Muhammadiyah Malang \\ uci.yuliati@yahoo.com
}

\author{
Triningsih S. \\ University of Muhammadiyah Malang \\ Triningsih019@gmail.com
}

\begin{abstract}
Small businesses Malang are the businesses located in Malang. They have limited capitals and assets with less than ten employees. These enterprises can be run by handicapped people and its survival is depended on workers employed. It means that if the workers do not have good performance, business' sales decreases. The purposes of this study are to know the factors of entrepreneurship and the characteristic on handicapped owners. Respondents are 22 people of the small business handicapped owners who operate their own business activities. This study requires a purpose that the respondents were chosen by using specific criteria based on handicapped business owner who run their business at least two years. Data was collected by using questionnaire and interviews. The methods of analysis are factor analyses and cross-tabulation. The result of analysis showed that the factors of entrepreneurship are entrepreneurship spirit, leadership skill, discipline, positive mentality and workers orientation. The characteristics of entrepreneurs are namely ability to sale, looking for opportunities, optimistic, strong heart, leaders skill, discipline, initiative, good spirit, analytical skills, understanding creative production, risk taker, selfreliance, be creative, be honest, product oriented, positive mentality, workers orientation.
\end{abstract}

Keywords: entrepreneurship, entrepreneur characteristics, handicapped, business owner.

\section{INTRODUCTION}

Small businesses managed by handicapped managers can provide income for their families. Small businesses can thrive in line with the storm of economic crisis that has been hit the economy of Indonesia. The spirit and enthusiasm of entrepreneurship that has been ingrained does not seem to affect the storm of the economic crisis. This means that small businesses have robust business and it is understandable because it requires relatively small capital with a small number of workers. Furthermore, the profit is not really remarkable but its consistencies and routine can promise as income that can be enjoyed by both the owner and his workforce.

In Malang there are many small businesses located in various areas that become business centers such as in
Sanan area, Talok area, as well as Dinoyo area. Small business owners who manage their business certainly have an entrepreneurial spirit. A physically normal business owner will more likely lead to a high entrepreneurial spirit and enable their business has a high performance as well. Nevertheless, there are businesses owners who are physically handicapped attract people to investigate. It is still questionable, whether with the entrepreneurial spirit; the handicapped entrepreneurs can also make a highperforming business. However, handicapped business owners can also employ physically-normal workers.

Another factor enable business owners have good entrepreneurship is the skills of small business owners, and the ability to motivate their business activities. In addition, the entrepreneurial spirit and family background also play a role in the business process that has been previously conducted [1]. Entrepreneurship knowledge and skills can significantly increase the income of small businesses. In addition to the skills of small business owners, the sustainability of their business can be run, among others, because (1) economic conditions, (2) demand (3) skills and creativity, (4) opportunities and organizational factors. Small businesses in Malang have huge diversity on its products and types of business. When it was seen from the workforce, it can be classified on small businesses because the number of workers who are less than 10 people. When it was seen from the amount of workforce can be referred to as a medium-sized enterprises, but because the investment value of less than 650 million then referred to as small businesses.

The existence of small businesses operated with of limited resources can produce a daily product and other affordable price products. Therefore, the spirit of entrepreneurship of the owners motivates the operations of small businesses and keeps it run continuously. There are several factors that make business owners successfully run their business with the limitations that in turn changed into an advantage. There are also several characteristics of a successful entrepreneur, among others, have a realistic dream to achieve, likes challenges, has strong ambition and motivation, has a strong belief, visionary, able to sell and market their products, innovative and creative [2].

In other words, it can be said that the success of small business is supported by several factors such as opportunity, human, financial, planning, organizational, 
planning, business management, marketing and sales, administration, and regulatory. The above factors are theoretically easy to say but interesting to examine whether these factors exist in handicapped business owners in Malang 1) what are the entrepreneurship factors of handicapped business owners in Malang?, and 2) what are the entrepreneurship characteristics of handicapped business owners?

\section{METHOD}

Respondents of this research were the handicapped business owner in Malang. The data was collected by using questionnaire and interview aims to know the factors of entrepreneurship used factor analysis. Factor analysis will perform entrepreneurial factors of the handicapped business owner in running their business. Respondents are the owners of small businesses in Malang who have physical deficiencies (handicapped) but they pursue various business fields. In addition, tabulation analysis used to know the characteristics of entrepreneurs of small business owners used, while the research variables include entrepreneurship factor and entrepreneurial characteristic.

\section{RESULT}

The results of this study include entrepreneurship factors of handicapped business owner and entrepreneur characteristics. The details are described as follows.

\section{Entrepreneurship Factors}

According to the factor analysis, there are five factors that determine entrepreneurship of handicapped business owner in Malang. The five factors are as the following table. Based on 30 entrepreneurial factors turn out to group into factors that have eigenvalue more than one and have components value more than 0.500 . Thus, it can be said that there are 5 entrepreneurship factors for handicapped business owner in running their business. The first factor is entrepreneurship spirit in running the business and the second factor is leadership skill and the third factor is discipline. While the fourth and fifth factor is positive mentality and workers orientation, respectively.

\section{The Entrepreneur Characteristics of Handicapped Business Owner}

Handicapped Business Owner is a manager who runs their business with physically insufficient and have good motivation to run their business. The characteristic of entrepreneur on the handicapped business owner are the ability to sell, look for opportunities, optimistic, strong heart, leadership skill, discipline, initiative, good spirit, analytical skill, understanding creative production, risk taker, self-reliance, always creative, always honest, positive mentality, worker

\section{DISCUSSION}

The factors of entrepreneurship are 5 factors namely entrepreneurship spirit, leadership skill, discipline, positive mentality and workers orientation and it relates to the characteristic of entrepreneur of handicapped managers. It means that five factors can support the handicapped manager to run their business because if such characteristics belong to them. The characteristics possess by the handicapped manager means they have behavior relating to the entrepreneurship skill. The first factor is the entrepreneurship spirit because in reality all handicapped managers run their business supported by their own inner spirit.

The second factor is leadership skill. Manager is the leader of the management activities conducted by the handicapped business owner who can be the manager in their business. The business can be supported by the managers as the business owner who has a lot of activities. All business activities are controlled by the business owner who has the skill of leader. Although they are handicapped but they can do the leadership skill they have.

The third factor is discipline. The handicapped business owners can run their business when they are discipline to do something they want to do from the morning to the afternoon. Their activities can be done routine and in sequence. For the cake seller, in the morning, they prepare to buy raw material to make many various products. And for the tailor, they open their shop and the worker to do their job such as design the model, cutting, and sewing, ironing and packaging. Finally, the owner informs the customer that their cloth finished. After taking their cloth booking, the customer paid the cost of sewing. Those

Table1. Entrepreneurship Factor of Handicapped Business Owner

\begin{tabular}{|r|c|l|}
\hline Factor & $\begin{array}{r}\text { Eigen } \\
\text { values }\end{array}$ & \multicolumn{1}{c|}{ Component } \\
\hline 1 & 8.154 & $\begin{array}{l}\text { Ability to sell, Seeking opportunities, } \\
\text { optimistic attitude, Constancy, } \\
\text { Leadership, Discipline, Initiation, } \\
\text { Spirit, Thoughtful Thinking, } \\
\text { Producing Creativity, Taking Risks, } \\
\text { Ability, Risk Courage } \\
\text { Independent in lead, always creative, } \\
2\end{array}$ \\
3 & 4.120 & $\begin{array}{l}\text { Always Spirit, Always honest, } \\
\text { Discipline of working time, Work- } \\
\text { oriented } \\
\text { Positive Mental Attitude, } \\
\text { Employee oriented }\end{array}$ \\
\hline
\end{tabular}


Table 2. Characteristics of Entrepreneurship of Handicapped Managers

\begin{tabular}{|l|c|c|c|}
\hline \multicolumn{1}{|c|}{ Entrepreneurial Characteristics } & \multicolumn{3}{c|}{ Number of Answers (\%) } \\
\hline Ability to sell & Strongly Agree & Agree & Disagree \\
Looking for opportunities & 50 & 22.7 & 27.3 \\
Optimistic & 59.1 & 40.9 & 0 \\
Strong Heart & 81.8 & 9.1 & 9.1 \\
Leaders skill & 54.5 & 27.3 & 18.2 \\
Discipline & 63.6 & 31.8 & 4.5 \\
Initiative & 59.1 & 40.9 & 0 \\
Good Spirit & 72.7 & 18.2 & 9.1 \\
Analytical skills & 86.4 & 0 & 13.6 \\
Understanding creative production & 54.5 & 36.4 & 9.1 \\
Taking into account the Risks & 63.6 & 27.3 & 9.1 \\
Self-reliance (Independent in lead) & 59.1 & 31.8 & 9.1 \\
Always creative & 59.1 & 40.9 & 0 \\
Always be honest & 63.6 & 36.4 & 0 \\
Product Oriented & 72.7 & 27.3 & 0 \\
Work-oriented oriented & 63.6 & 36.4 & 0 \\
Positive Mental Attitude & 54.5 & 45.5 & 0 \\
Oriented to employees & 59.1 & 38.4 & 0 \\
\hline
\end{tabular}

The forth factor is positive mentality. Thinking positive is very important for doing business, especially for their mentality. It means that positive mentality is one of attitude that supports the handicapped business owner for running their business relating to their own inner motivation. They are always doing it no matter what the problems they are facing. Having positive mentally support the handicapped business owner stronger and have positive direction. Finally, they are able to reach want they want to have or to do.

The fifth factor is worker orientation, described as an attitude to deal with the worker they employ. The workers should be trained at the first because they can do all the business activities in the coming time. The workers who are educationally low could support the handicapped business owner to have good supervision to them. Therefore, the worker has good spirit as long as they work in the small businesses.

The characteristic of handicapped manager were belonging to taken by the all handicapped business owners. The characteristics of entrepreneurs are namely ability to sale, looking for opportunities, optimistic, strong heart, leader-skill discipline, initiative, good spirit, analytical skills, understanding creative production, risk taker, selfreliance, always creative, always honest, product oriented, positive mentality, workers orientation.

The ability to sale means that all handicapped managers are able to sale their product because it was good and needed by consumers. The second characteristic was ability to look for the opportunity for selling their product because they have good networking called association of handicapped business owners. They have routine meeting to discuss their problem facing in their business. They also have social activities such as giving charity to the poor.

The third characteristic was optimistic which can support owner as manager to do all operation. It means that they highly believe any activities they want to do would be success. This character is referred to as the entrepreneurial spirit factor that exists in the handicapped business owner. It also related to the leadership characteristic, discipline, initiative, and patient [3]. It means that when the business owner runs their leadership, directly they should have been discipline, initiative and patients. The business owner who is also the leader should directly do patient and having initiative and discipline.

Understanding creative production was also determining their success, because they should do the production creatively. This will lead them to the awareness of having the best performances [4]. High quality product can only be produced in creative way.

Risk taker is the characteristic relate to their behavior to take risks when they make decision. It means that every decision have its own risks. Risks taker can be the consequences all the handicapped business owner. Selfreliance is the attitude to do the activities independently. It means that although they are physically insufficient they can manage their business.

When the business owner meets the customer to explain about the product they want and need. The costumer need product based on their desire [5]. Therefore, the business owner should be able to fulfill what they want. It means that they are always creative as long as running their business.

Facing many type of customers, the business owner should do all the business activities honestly. It is also for 
keeping the customer loyalty. They should never lie, inform the real condition. Furthermore, they also should have a good orientation on the product. The product oriented mean that they always aware that the good product is customer demand. Therefore, product orientation is important to be good attitude. The unique thing is that the handicapped business owner has an orientation on the outcome or the product as well as giving their customer satisfaction. Positive mentality is the characteristic relate to the mind-set, how they think everything in a good way (husnudzon/positive thinking). Workers orientation is the characteristic relate to attention given when the handicapped business owner to do their activities.

\section{CONCLUSION}

The conclusions of this study are the factor of entrepreneur on handicapped manager. There are five factor namely entrepreneurship spirit, leadership skill skill, discipline, positive mentality, and orientations. In addition, the characteristics of entrepreneurs as the handicapped managers were ability to sale, good looking for opportunities, optimistic, strong heart, leadership skills, discipline, initiative, good spirit, analytical skill, understanding creative production, risk-taker, self-reliance, always creative, always honest, product oriented, positive mentality and worker relations.

\section{REFERENCES}

[1] Alma, Buchari, Entrepreneurship, Bandung, Ikatan Penerbit Indonesia (IKAPI) 2000.

[2] Ass'ad, M., Industrial Psychology, Yogyakarta, Lyberty. 1991,

[3] Cohen, Entrepreneurship and Small Business Problem Solving, 2nd ed., Singapora: John Willey \& Son. 1990.

[4] George, JM. Dan Zhou, J., When Opennes to Experiences and Conscientiusness are Related to Creative Behaviour: An Internal Approach. Journal of Applied Psychology, Vol 86,No.3, 2001.

[5] Hendro, Entrepreneurship: Tips to Success , Graha Science, Jogjakarta, 2008.

[6] Longenecker, G.,Justin, Entrepreneurship, Manajemen Usaha Kecil, Buku satu, Jakarta, Salemba Empat, 2001

[7] Longenecker, G.,Justin, Entrepreneurship, Small Business Management, Buku dua, Jakarta, Salemba Empat. 2001.

[8] Maskur, Wiratmo, Pengantar Entrepreneurship, Kerangka Dasar Memasuki Dunia Bisnis, YogyakartaBPFE-UGM, 1996.

[9] McGrath, dkk., Elitist, Risktakers, and Rugged Individuals? An Explatory Analysis of Cultural
Dofferences Between Antrepreneurs an NonEntrepreneurs, Journal of Business Ventury, 7(2), 1993.

[10] Meredith, G., Geoffery, Entrepreneurship, Practice and Theoritical, Jakarta, Pustaka Binaman Pressindo, 1992.

[11] Suryana, Entrepreneurship, Practical Guidance, Tips for Succes Prosses, Jakarta, Salemba Empat. 2003.

[12] Scott, S.G. dan Bruce, R.A., Deterninant of Innovative Behaviour: A Path Model of Individual Innovation in the Workplace. Academi of management Journal Vol 37, no. 3,19 